\title{
An Infrastructure Factor in Regional Competitiveness
}

\author{
Valentina Nikolaevna Komarova \\ Olga Vasiljevna Zjablova
}

\section{Ramil Rafailovich Denmukhametov}

Kazan Federal University, Russian Federation, 420008, Kazan, Kremlyovskaya str., 18

\section{Doi:10.5901/mjss.2014.v5n18p355}

\section{Abstract}

This research deals with the role of infrastructure in the development of sustainable and competitive development of the territorial, socio-economic system of the region. Individual components of the regional infrastructure and their contribution to the territories' development are defined. Economic and geographic analysis of the competiveness of the six economic regions in the Republic of Tatarstan is conducted. The analysis is based on comparison of various indicators, which characterize distribution and quality of infrastructure facilities. Spatial habitats with high competitive development potential are defined by further increasing of an agricultural specialization and establishing of vertically and horizontally integrated production structures. They are industrial, economic regions which concentrate the main part of popularity and funds and identify perspective opportunities of economic restructuring. The second group of areas have at most agrarian and industrial specialization, and more often just agrarian as inert sphere of socio- economic space of the region.

Keywords: regional infrastructure, regional competiveness

\section{Introduction}

Nowadays it becomes important to find new ways and important factors in regional development [1-6]. It is linked to the impact of common trends, such as depletion of traditional sources of socio-economic development, the emergence of the network forms of organization, increase of the intellectual component in the production results, fast development of the service sector, building postindustrial society, active informatization of society and globalization [7-9].

In the book "The Stages of Economic Growth" W. Rostow [10], Professor of Cambridge University, states that any society in the economic development deals with one of the five stages:

1) "Traditional society" with primitive technology, where agriculture is dominated, family and clan ties play a certain role;

2) "Transitional society" is a prerequisite for development, when conditions for the development appear, "New Elite" appears. Nationalism which is the reaction to the more developed countries' influence and the leading force for changes appears;

3) "Take - off stage" is the stage, in which the share of national income, aimed at investment and savings grows. The profit gained is reused as capital, new industries rapidly grow and cities grow because of the industrialization;

4) "The movement towards maturity" is the stage, which is typical for society with diversified structure of farms in the economy. The automobile, chemical, electrical engineering industries and complex automobile construction develop;

5) "The era of mass consumption" is the stage, where the economy structure changes in favor of the service sector and production of technically complex durable consumer goods [11].

\section{Research Methodology}

Regional development and competitiveness

Analyzing regional development, it is preferable to define three main stages, such as the pre-industrial stage (extractive industries, agriculture, fish industry, forest industry and mining industry are the dominating sectors); industrial (processing industries, such as automobile construction, forest industry, the chemical industry, light industry and food 
industry, etc. are dominating); the post-industrial stage, which might be characterized by a relative drop in production of goods and a relative increase in the role of services, knowledge - intensive service growth and dynamic internationalization activities.

Regional development might be represented in the form of sustainable and effective complication of social, ecological and economic systems. Thus, the competitiveness is understood as high efficiency of individual manufacturing sectors, producing innovative and competitive products in the process of saving the system integrity and under the conditions of internal and external influences.

The effectiveness of the system is considered to result in the predominance of the organization's processes over destruction processes. It creates opportunities for further complication.

The complication of the system is enhancement of its structural, information diversity. Appearance of new elements, production and control levels, expanding of new products and services are the result of increasing the system diversity. It turns the region into the undersaturated market and enables it to get innovative profit.

As it is noticed in many studies regional development is connected with various factors [4, 8, 12]. Most traditional studies note that for competitive development of the area it is necessary to combine labor resources and natural resources, technical basis and financial resources. Human resources availability of the region is defined by economically active working population, which has appropriate standard of education; by a number of people, who have higher and secondary - level education and deal with national economy. Creative potential, human knowledge and strong educational system are very important factors in fund raising of the region and consequently, in its development.

Natural resources are considered as free lands for productive investment, for region's supply with water resources, for wooded lands and mineral products etc. An important positive factor would be maximum proximity of production facilities to natural raw materials.

The technical basis and equipment help to develop old and traditional industries, at the same time it helps to create new production facilities and to form a diversified economy, as the basis for competitive development.

Financial factors assess the profitable part of the budget in the region (a budget deficit contributes little to the investment attractiveness of the region); contribution of population into investment process; credit availability and the share of unprofitable enterprises in the region. Regions might have sustainable growth at the combination of the three factors, i.e. when natural resources are limited, but not the population, equity or imported capital and technology. At the same time any of these critical factors might function as a constraint for development.

Modern researchers $[3,7,13]$ interpret the combination of the factors in regional development more broadly, including additionally to the mentioned above the following:

- organizational (the relation of the regional authorities to investors, including the existence and enforcement of laws, protecting the rights of investors, and proving benefits for them; compliance with legislation by the region's executive authorities; the rights in culture of entrepreneurs); information (information support in the region; information system adequacy is the system of processing information, updating of information, transferring of information with the help of computer and other technologies, information access);

- innovative in the form of scientific and technical capacity (a number of research institutions in the region, which make economically significant scientific developments; a number of new machines' samples, technical equipment, including a number of innovative projects, implemented in production, their cost - effectiveness and funding of scientific research; the share of funds in regional budget allocated to education);

- economical and geographical location factor (EGLF) of the region is defined by the relation to the areas with primitive, agricultural, industrial, service and information economy, as well as the relation to poles of growth , financial and information centers, building mutually beneficial cooperation with regional leaders driven by their proximity, it determines the importance of assessing EGLF for the regional development;

- $\quad$-social and socio-cultural factors (i.e. the standard and the quality of living of the region's population [14]; crime wave and crime structure); the impact of migration upon the investment process; working conditions for foreign specialists);

- infrastructure (all forms of infrastructure development in the region, including material one, such as roads, bridges, harbors, communication, housing and cultural - domestic facilities [1, 5];

- institutional, which includes a set of institutions of the State Government structure, organization costs, maintenance of monetary and financial system ( market infrastructure);

- personal, which deals with investing in education, health care, culture and other services.

- In geographical researches infrastructure is defined as a set of constructions, buildings, and systems, i.e. it is immobile part of the main funds, which provides material conditions for normal, reproductive process. Consequently, infrastructure cannot be moved from one region to another, only gradual development is 
possible within a certain space. Thanks to this infrastructure and all its elements are closely connected with areas and all the economy development processes, they form the shape of a geographical entity and territory. Infrastructure and competitive development of the area.

I.M. Maergoiz [15] proposed the term 'geographical infrastructure', which means a set of constructions, which are necessary for the process of economic managing and providing the normal material and cultural - living conditions for the population in the area. Thus, infrastructure includes the main funds, such as buildings, different constructions, devices, networks, etc., which are attached to the ground and function as the basis for economic activity in the region.

Fixed assets (FA) could be examined as economical resource. They are the measures of the economic power and basis of the current economy production. That is why, investigating geographical aspects of the sustainable development, infrastructure and fund measures could play a larger role, rather than traditional geographical characteristics. Particular attention should be paid to the study of such economy area trends as accumulation of funds in the region, their geographical peculiarities in connection with the production placement and resettlement. It is an important fact, that modern technologies reduce the share of human labor and increase the share of embodied labor.

Important indicators for general fund areas could be following:

- the absolute value of FA;

- the amount of FA per unit area (it characterizes the territorial fund saturation);

- the amount of FA per one inhabitant (or working in the sphere of economy). It characterizes the social viability of the territory (and economy extensiveness);

- $\quad$ the composite economic index " $k$ ", defined as ratio of FA to the square root from multiplication by population size and area size;

Calculation of indicators is based on annual economic and socio- demographic report materials of the Rural Administration by Federal State Statistics Service of the Russian Federation in the Republic of Tatarstan.

Using given area fund saturation indicators, it is possible to identify territorial differentiation between areas and therefore, attractive ones in terms of investment. Infrastructure differences could serve as the basis for sociogeographical zoning and identification of socio - territorial inequality.

The overall development level of infrastructure is directly connected with the staging of socio - economic development of the region. Theoretically, when any region enters a new stage of development, infrastructure upgrade is essential $[2,9,16]$.

\section{Results}

Infrastructure factor in competiveness of economic regions in the Republic of Tatarstan.

The general amounts of infrastructure development, calculated per unit area practically coincide with the area border according to the development stages. It is represented in comparison of figures of administrative- territorial units, which are administrative districts and cities of the Republic of Tatarstan (table 1).

There are six economic regions on the level of consolidated areas. Slight reduction in territory contrast happens on the fund saturation. The difference is dozen of times; it allowed separating two equal territory parts of the Republic of Tatarstan , but with different growth stages. They are secondary industrial - agrarian and primary industrial - agrarian.

Table 1. Fund saturation of Economic Regions in the Republic of Tatarstan

\begin{tabular}{|l|c|c|c|c|c|c|}
\hline $\begin{array}{l}\text { Economic } \\
\text { Regions }\end{array}$ & $\begin{array}{c}\text { Proportion of the region in the } \\
\text { demographic structure of the } \\
\text { Republic of Tatarstan \% }\end{array}$ & $\begin{array}{c}\text { Proportion of the region } \\
\text { in the territory of the } \\
\text { Republic of Tatarstan \% }\end{array}$ & $\begin{array}{c}\text { Proportion of the } \\
\text { region in the capital } \\
\text { assets of economy, \% }\end{array}$ & $\begin{array}{c}\text { FA per } \\
\text { sq.km., } \\
\text { RUB mln. }\end{array}$ & $\begin{array}{c}\text { FA per a } \\
\text { person, } \\
1000(R U B)\end{array}$ & $\begin{array}{c}\text { The composite } \\
\text { economic } \\
\text { index "k", }\end{array}$ \\
\hline North West & 38,8 & 16,1 & 31,1 & 14,8 & 110,1 & 40 \\
\hline North East & 29,1 & 21,8 & 28,9 & 10,2 & 136,9 & 37 \\
\hline South East & 14,9 & 16,7 & 30,1 & 13,8 & 278,7 & 62 \\
\hline Zakamye & 7,6 & 20,7 & 3,7 & 1,3 & 66,6 & 10 \\
\hline Predkamye & 5,5 & 13,5 & 1,4 & 0,8 & 34,8 & 5 \\
\hline Predvolzhye & 4,1 & 10,8 & 1,2 & 0,8 & 39,6 & 6 \\
\hline Total & 100 & 100 & 100 & 7,6 & 137,4 & 32 \\
\hline
\end{tabular}

It is a well-known fact that various human activities require infrastructural arrangement. The leas demanding are forest and agricultural activities, i.e. typical for the pre-industrial stage of development. Industrial activity and rapid urbanization 
lead to the growth of requirements on infrastructure types and scale.

Within industrial regions, some features of the post-industrial stage appear in big cities. Infrastructure industries become the main sector for sustainable and competitive development.

The potential of postindustrial regions and capacity to take new business types depends on the road infrastructure, communication, housing, service and availability of office facilities.

In comparison with other economy sectors, infrastructure development is considered to have forward -looking nature.

Thus, infrastructure not only links different territories, but also differentiate them, creating socio - territorial inequality.

The table analysis allows noticing more or less even distribution of a single indicator, such as the proportion of the region in the territory of the Republic of Tatarstan. The ration between maximum and minimum value is 1:2. Other indicators show that there are two unequal groups of economic regions in terms of development in the Republic of Tatarstan.

The first group includes "Industrial economic regions", which concentrate the majority of the population and funds of the Republic of Tatarstan. They also determine perspective opportunities of the structural reorganization of the economy. The second group of regions, which at least have agrarian and industrial specialization and more often just agrarian one function as inert sphere of socio-economic space of the region.

\section{Summary}

It is difficult to overestimate the role of infrastructure as the factor of the region competiveness. It is the basis, "the frame" for development of core as well as local industries. Mass consumption population" promotes further development of service sphere and involvement in it. Investigations of infrastructure have integrated nature. They reflect its special features, results in economic development, social importance and assessment of spatial streams in implemented services.

\section{Conclusion}

A significant increase of competitive production assets (petrochemical industry, automobile construction and agriculture) is observed in the investigated region. Their further development at most is connected with the improvement of infrastructure sectors, especially in traditional agrarian regions. The research has illustrated the fact that areas with high industrial status and concentration of infrastructure are considered to be in most favorable situation to develop competitive production. The other regions significantly lay behind in terms of possible growth.

\section{Findings}

Infrastructure level of development is one of the important indicators in the development of the region. Regardless of the specialization, the establishment or further strengthening of competitive economy industries is impossible without complexity and the qualitative improvement of the whole Infrastructure Complex of the region.

\section{References}

Kovacs, G. and K.M. Spens, 2006. Transport infrastructure in the Baltic States post-EU succession. Journal of transport geography (14), 6: 426-436. DOI: 10.1016/j.jtrange0.2006.01.003.

Wokoun, R, 2009. Regional Competitiveness And Regional Development Factors In The Czech Republic. Proceedings of the: 3rd Central European Conference in Regional Science, OCT. 07-09 Kosice, Slovakia, pp: 893-900.

Surd, V., I. Kassai and L. Giurgiu, 2011. Romania disparities in regional development. Proceedings of the 2nd International Geography Symposium-Mediterranean Environment, JUN. 02-05, 2010, Antalya, Turkey. Book Series: Procedia Social and Behavioral Sciences (19), pp: 21-30. DOI: 10.1016/j.sbspro.2011.05.102.

Jermolajeva, E., and S. Cingule-Vinogradova, 2012. Potential of Latgale Region and Directions of the Development. Proceedings of the 13th International Scientific Conference on Economic Science for Rural Development, APR. 26-27. Latvia Univ Agr., Fac. Econ., Jelgava, Latvia, pp: 100-106.

Del Bo, C.F. and M. Florio, 2012. Infrastructure and Growth in a Spatial Framework: Evidence from the EU regions. European planning studies, 20 (8): 1393-1414. DOI: 10.1080/09654313.2012.680587.

Denmukhametov, R.R., O.V. Zjablova and M.R. Shtanchaeva, 2014. Development factors of Kazan region recreation area. Life Science 
Journal, 11(11): 317-320.

Lvov, D.S., A.G. Granberg and A.P. Egorshin, 2005. Strategic Management: region, city, business. Social Sciences Institute of Russian Academy of Sciences. Moscow. Economics Publishing, pp: 603.

Komarova, V.N., 2006. Analysis and assessment of internal and external factors affecting the regional development. In Mathematics in Geography: Yesterday, Today and Tomorrow, Ed., Trofimov, A.M. Kazan: Meddok Publishing, pp: 134-145.

Komarova, V.N. and A.M. Trofimov, 2007. An infrastructure factor in regional competiveness. In Geosituational analysis. Ed., Trofimov, A.M. Kazan: Meddok Publishing, pp: 53-64.

Rostow, W.W., 1990. The stages of economic growth a non-communist manifesto. 3rd ed. Cambridge University Press in Cambridge [England], pp: 272.

Muntean, I.M. and A.D. Ursul, 2003. Global Processes and Sustainable Development. Moscow: Stupeni Publishing, pp: 302.

Vardomsky, L.B., 2001. Russia in the context of external policy: Regionalization problems in the context of regional process dynamics. In Regionalization in the development of Russia. Geographical processes and problems. Russian Academy of Sciences: Institute of Geography press, pp: 67-86.

Crescenzi, R. and A. Rodriguez-Pose, 2012. Infrastructure and regional growth in the European Union. Papers in regional science, 91 (3): 487-513. DOI: 10.1111/j.1435-5957.2012.00439.

Hajek, P. and V. Hajkova, 2009. Modelling Quality of Life in Regional Centres. Proceedings of the 3rd Central European Conference in Regional Science, OCT. 07-09 Kosice, Slovakia, pp: 1026-1038.

Maergoiz, I.M., 1986. The territorial structure of the economy. Novosibirsk: Nauka Publishing, pp: 302.

Zenka, J., J. Novotny and P. Csank, 2014. Regional Competitiveness in Central European Countries: In Search of a Useful Conceptual Framework. European planning studies (22), 1: 164-183. DOI: 10.1080/09654313.2012.731042. 
